\title{
FGFR3 NM_000142.4:c.1138G>A
}

National Cancer Institute

\section{Source}

National Cancer Institute. FGFR3 NM 000142.4:C.1138G>A. NCI Thesaurus. Code

C128906.

A nucleotide substitution at position 1138 of the coding sequence of the FGFR3 gene where guanine has been mutated to adenine. 